\title{
A Global Perspective on Effectiveness of Aid for Trade
}

\author{
Maria Berrittella • Jian Zhang
}

(C) Springer Science+Business Media New York 2013

\begin{abstract}
Recent global initiatives on debt relief and development assistance call for increasing aid for trade to the poorest countries. We apply a multi-country computable general equilibrium model to measure the effectiveness of alternative aid for trade categories. Our findings show that aid for trade policies expand trade and alleviate international income inequalities in the recipient countries, that will benefit mainly from aid for trade adjustment and technical assistance.
\end{abstract}

Keywords Aid for trade - Computable general equilibrium model · Income inequality Trade balance . Welfare

JEL Classification $\mathrm{C} 68 \cdot \mathrm{F} 13 \cdot \mathrm{F} 59 \cdot \mathrm{H} 77$

\section{Introduction}

International trade can be a powerful driver for economic growth, poverty reduction and long term sustainable development. For many developing countries, especially least developed countries, trade related bottlenecks, such as lack of market information, ineffective policies, weak private sector, poor institution and infrastructure, prevent them to integrate and compete in the global market. Aid for trade (thereafter, AfT), launched in 2005 at Hong Kong WTO Ministerial Conference, provides the financial and technical assistance that aims to facilitate the integration of low-income countries into the global economy. In particular, the AfT policy actions include initiatives that reduce transaction costs and enhance productivity in order to expand

We are grateful to an anonymous referee for helpful comments and suggestions.

M. Berrittella $(\bowtie)$

Dipartimento di Scienze Economiche, Aziendali e Statistiche, Università degli Studi di Palermo, Viale delle Scienze, 90128 Palermo, Italy

e-mail: maria.berrittella@unipa.it

\section{J. Zhang}

The World Bank, 1818 H street, NW, Washington, DC 20433, USA 
trade and alleviate inequality in recipient countries (Hoekman and Wilson 2010). Under the current rapid changing geopolitical environment, multi-dimensional financial crisis and unevenly income distribution, the need for further aid assistance has been widely recognized by multi-donors and the international foreign aid community. The openness to trade is a key ingredient for economic success and for improved living standards, but reductions in trade barriers is not enough. Thus, the aim of aid for trade policies is to help these countries overcome the supply-side and trade-related infrastructure constraints that inhibit their ability to benefit from market access opportunities (WTO/OECD 2011).

AfT is an integral part of regular official development assistance (ODA). The Organization for Economic Cooperation and Development (OECD) reports continuing growth in ODA. In fact, in 2009, the rise in ODA in real terms was about $7 \%$. The largest donors were the United States, France, Germany, the United Kingdom and Japan. Also ODA increased by nearly $30 \%$ in real terms between 2004 and 2009, and it is expected to rise by about $36 \%$ in real terms between 2004 and 2010. The continued growth in ODA has shown that aid pledges are effective when backed up with adequate resources, political and firm multi-year spending plans. There has also been an emerging consensus that the WTO Doha Round must be coupled with adequate trade-related assistance to mitigate the detrimental effects of trade reforms and to enhance the trading capacity of developing countries. Specifically, in February 2005, G-7 Ministers called on the World Bank and the International Monetary Fund (IMF) to develop proposals for additional assistance to countries to ease adjustment to trade liberalization and to increase their capacity to take advantage of more open markets. Subsequently, in July 2005 Heads of State at the G8 Summit at Gleneagles agreed to increase help to developing countries to building their physical, human and institutional capacity to trade. In December 2005, at the $6^{\text {th }}$ Ministerial Conference held in Hong Kong, the Ministerial Declaration endorsed the enhancement of the Integrated Framework and created a new WTO work programme on Aid-for-Trade (Hoekman and Wilson 2010).

Since 2005 donors and development agencies have increased the overall value of AfT and put in place several mechanisms to channel such aid and to ensure that it alleviates inequality. According to the data reported by the OECD, $25 \%$ of the official development assistance (ODA) was directed toward AfT in 2008. Also OECD statistics show that in 2009, global AfT commitments reached approximately 40 billion US dollars, a $60 \%$ increase from the 2002- 05 baseline period. Half of all AfT is provided in grant form, mainly to the poorest developing countries. Disbursements have been growing at a constant growth rate of between 11 and $12 \%$ for each year since 2006 - reaching 129 billion US dollars in 2010-indicating that past commitments are being met (WTO/OECD 2011). The top three developing regions that received the aid from all donors are Asia, Africa and South America respectively in the past decade (Fig. 1). ${ }^{1}$

The literature on AfT is really quite new (e.g. Helble et al. 2009; Hoekman and Wilson 2010; Calì and Velde 2011). In part this is because of data limitation; frequently, because it will be difficult to disentangle the impacts of AfT projects on trade, income

\footnotetext{
${ }^{1}$ The Aid data set is extracted from OECD.STAT data base. The donors include DAC countries, multilateral agencies, non-DAC countries, G7 countries, DAC-EU members.
} 


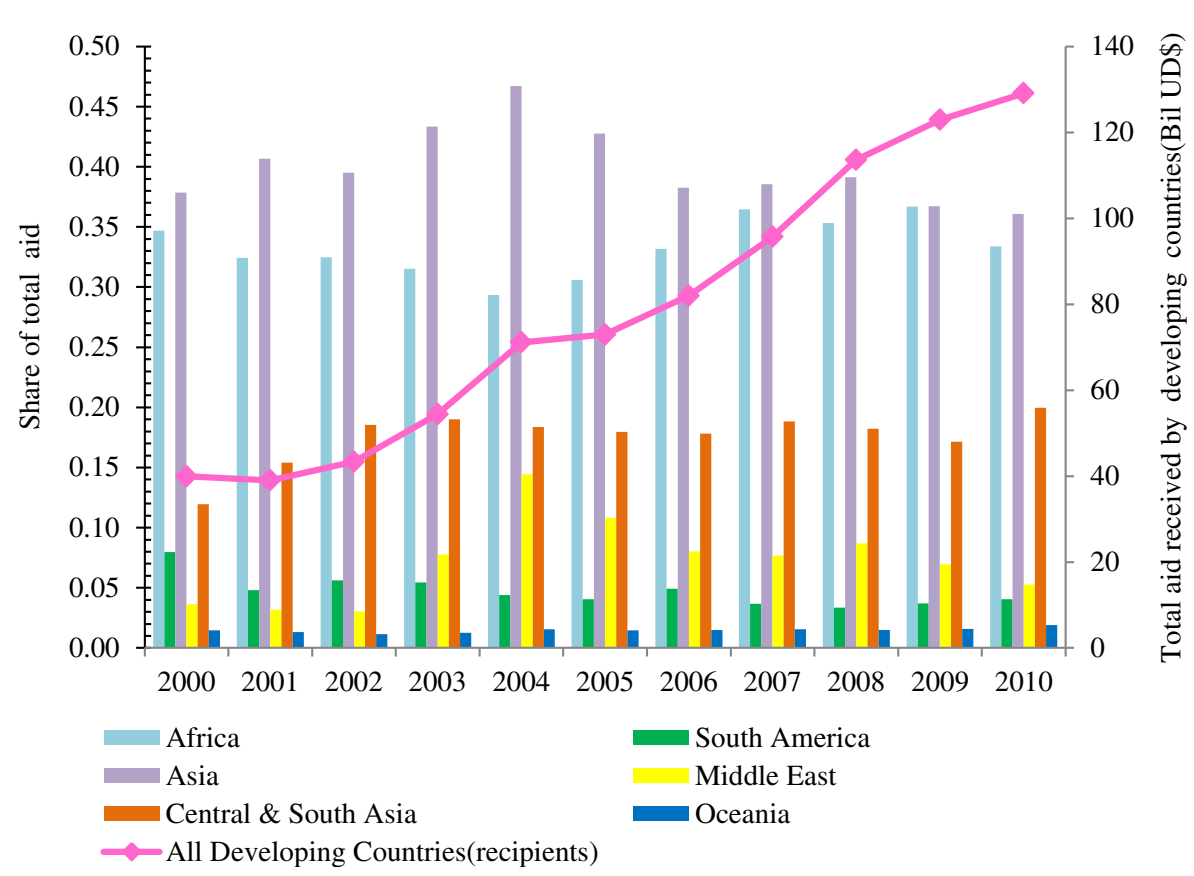

Fig. 1 Foreign aid distribution to Developing Countries by Region. Source: Our calculation from OECD.STAT data base

and welfare. However, the literature on AfT can be traced back to that on foreign aid, whose role of foreign aid in the growth process and to reduce international inequalities in developing and least developed countries has been a topic of intense debate for several decades. This issue has been analyzed by researchers for decades due to its complexity in nature. It links with political relationship between donor countries and recipient countries, governance of public sector in recipient country, and how much the foreign aid is necessary and how long it should last.

The measurement of effectiveness of AfT, which is the core principle in the Paris Declaration on Aid for Trade, is extremely vital for the recipient countries, because the evaluation of the AfT impacts would allow policy makers of these countries to have a deep understanding of the key issues when they negotiate, design and implement the objectives of AfT. In this context, using a multi-country computable general equilibrium model, the aim of this paper is to analyse AfT policies in terms of effectiveness, which requires that AfT policies achieve their stated goals in the recipient countries.

A computable general equilibrium model (thereafter, CGE) describes an economy in equilibrium with endogenously determined relative prices and quantities. Whereas most empirical approaches examine the policy impacts or effects under a ceteris paribus condition, a CGE model, which provides comparative scenarios based on benchmark scenarios, incorporates factor markets, goods markets and external trade markets. Interactions and linkages that take place between these different markets are taken into account. Thus, CGE model allows of evaluating the effects of exogenous shift of policy variables on macroeconomic indicators, such as real GDP, trade balance and welfare. 
We concentrate our analysis to the main common priorities identified by the donor and recipient countries in the AfT distribution, which are expanding trade and alleviating income inequalities in the poorest countries (WTO/OECD 2011). The policy design includes four scenarios, which simulate the main AfT categories. In the first scenario, we simulate income transfers from the donor countries to the recipient countries assuming that AfT transfers are not constrained to any project or public expenditure. In the other three scenarios the AfT transfers are constrained to reduce, respectively, trade margins, to increase factor productivity and investments in the recipient countries.

The novelties of this paper are mainly two-fold. Firstly, this is an empirical analysis that it is not limited to one country, but allows of comparing the AfT effects among key aid recipients, which provides us an overview of effectiveness of AfT from global perspectives. Secondly, we compare all the ODA categories or instruments in support of trade proposed in the international debate, such as trade adjustment assistance (TAA), institutional reforms(IR), technical assistance and capacity building (TA \& CB) and economic infrastructure (EI) and integrate these instruments with global economy using more recent data, which no other literature have done so according to our best knowledge. Our findings show that AfT policies expand trade and alleviate inequalities in the recipient countries, which benefit mainly from aid for trade that supports these countries with any transitional adjustment costs from liberalization and increases factor productivity.

\section{Literature Review}

The literature on AfT can be related to that on foreign aid, which has produced quite different views. On the one hand, the process of foreign aid may deviate from its original purpose or objective due to various factors in each stage of foreign aid creation, implementation, grant distribution and monitoring system between donors and recipient countries. Bauer (1975) regards foreign aid as a failure for recipient countries defining foreign aid as "a transfer of resources from the taxpayer of a donor country to the government of a recipient country". Thus, foreign aid destroys economic incentives, and leads to misallocation of scarce resources and rent seeking, and finally reduces recipient countries economic growth. Based on both the history and the evidence on foreign aid, Easterly (2003) shares similar view as Bauer (1975) questioning about the alternative definition of "aid" "good policy" and "growth" to illustrate the complex relationship between foreign aid and growth and the high possibility of failure. On the other hand, we would find a large number of studies supporting foreign aid. The endogenous growth model developed by RosensteinRodan (1943) supports foreign aid. The idea beyond this model is that lack of sufficient investment or physical capital would hurdle economic growth; however, foreign aid provides investment capital, which would generate income and raise up the return to capital and promote economic growth. Burnside and Dollar (2000) and Collier and Dollar (2002) argue that foreign aid promote growth only in good policy environment. Ang (2010) finds that while foreign aid exerts a direct negative influence on output expansion, its indirect effect via financial liberalization is positive. Dalgaard and Hansen (2001) suggest that there is a linear effect between the aid- 
growth relationship due to diminishing returns to foreign aid. Dollar and Kraay (2001) suggest that good policies package such as private property rights, fiscal discipline, macroeconomic stability, and open to trade on average increase the income of the poor. Furthermore, there are some studies that found ambiguous or mixed relationship between foreign aid and growth. Bourguignon and Sundberg (2007) argue that the empirical literature on aid effectiveness has yielded unclear and ambiguous results. The "black box", which is the linkage from donors to policy makers, from policymakers to policies and from policies to outcomes, makes it difficult for researchers to quantify and open it. Rajan and Subramanian (2005) find no robust positive relationship between aid and growth by using cross-country panel data. Ekanayake and Chatrna (2010) find mixed effect of foreign aid on economic growth in developing countries. Werker et al. (2009) argue that foreign aid affects most components of GDP, but it has no statistically identifiable impact on prices or economic growth. Inanga and Mandah (2008) conclude that foreign aid finance can generate economic growth if effectively utilized in a stable macroeconomic environment. Finally, Holder (2004) argues that the relationship between foreign aid and growth turns out to be an inverted-U shaped under reasonable policy assumption, which is an Aid Laffer Curve. Positive relationship between foreign aid and growth is located in the upward sloped side of the Aid Laffer Curve, while the negative relationship is located at the downward sloped side of the Aid Laffer Curve.

The importance of AfT for the low income countries can be related also to the relationship between trade and economic growth. We would find a large number of theoretical and empirical studies that have examined this relationship. Main survey studies are Anderson and Strutt (1996) and Greenaway and Winters (1994). Winters and McCulloch (2000) carry out a theoretical analysis of the relationship between trade measures and their impact on poverty using both simple forms of static, and short and long term dynamic analysis. He identified a number of possibilities of both pro- and anti-poor influences and state that the effects of trade on poverty are likely to be positive providing a view about how trade liberalization can be designed to foster poverty alleviation. Balassa (1978) investigates the relationship between exports and economic growth for 11 developing countries. Statistical evidences were provided subsequently in several studies. Furthermore, there have been some studies which have provided important insights on how international trade liberalization influences economic growth, such as Feder (1982), Levine and Renelt (1992) and Wacziarg (2001). According to these studies, trade impacts on growth through creating new investments, positive external effects, technology transfers, inflow of foreign direct investments, productivity growth, etc.. A paper by Cockburn et al. (2005) draws on lessons on the impacts of trade liberalization on growth, poverty and inequality in seven Asian and African countries. The paper concludes that trade liberalization has positive, although generally small, effects on growth and poverty reduction occurs in most countries.

\section{Modeling Framework}

In order to assess the systematic general-equilibrium effects of AfT we use a Computational General Equilibrium (CGE) model, labeled AIDCGEM, which is a 
comparative static, multi-commodity, multi-region model with the assumptions of perfect competition, market equilibrium and open economy. The AIDGEM model is a modified version of the standard GTAP model (Hertel 1997).

As in the standard GTAP model, on the consumption side, the economy is modeled by a representative household in each region $r$, whose Cobb-Douglas utility function allocates expenditures between private consumption $(\mathrm{C})$, government consumption (G) and savings expenditure (S) as follows:

$$
U_{r}=C_{r}^{\alpha_{C, r}} G_{r}^{\alpha_{G, r}} S_{r}^{\alpha_{S, r}}
$$

with $\alpha_{\mathrm{C}, \mathrm{r}}, \alpha_{\mathrm{G}, \mathrm{r}}$ and $\alpha_{\mathrm{S}, \mathrm{r}}$ income shares and $\alpha_{\mathrm{C}, \mathrm{r}}+\alpha_{\mathrm{G}, \mathrm{r}}+\alpha_{\mathrm{S}, \mathrm{r}}=1$.

The constrained optimizing behavior of the household in region $r$ for private consumption is represented by a non-homothetic Constant Difference of Elasticity (CDE) expenditure function for the set of goods and services. A Cobb-Douglas subutility function is employed for government spending. In this case the expenditure shares are constant across all commodities. Private and government consumption are split in a series of alternative composite Armington aggregates (Armington 1969).

On the production side, the producers receive payments for selling consumption goods to the private households and the government, intermediate inputs to other producers and investment goods to the savings sector. Under the zero profit assumption, these revenues must be precisely exhausted on expenditures for intermediate inputs and primary factors of production. The nested production technology exhibits constant returns to scale and every sector produces a single output. The technology is simplified by employing the Constant Elasticity of Substitution (CES) functional form:

$$
y_{i, r}=\left(\sum_{j=1}^{n} \theta_{j} x_{j, r}^{1-\frac{1}{\sigma}}\right)^{\frac{\sigma}{\sigma-1}}
$$

where, in region $r, y_{i, r}$ is the production of the $\operatorname{good} i, \mathrm{x}_{\mathrm{j}, \mathrm{r}}$ is the input $j, \theta_{\mathrm{j}}$ is a nonnegative parameter, with $\sum_{j=1}^{n} \theta_{j}=1$, and $\sigma$ is the elasticity of substitution.

Both intermediate and final products from different regions are considered to be imperfectly substitutable with each other (Armington 1969). All factor inputs (land, labor, capital and natural resources) are assumed to be fully employed and immobile across regions. Capital and labor are perfectly mobile across sectors and, hence, they earn the same market return regardless of where they are employed; land and natural resources are sluggish to adjust and their returns may differ across sectors.

Savings are exhausted on investment and capital markets are assumed to be in equilibrium only at the global level. If savings exceed investments for one country, then it has a trade surplus; otherwise, it has a trade deficit. A hypothetical world bank collects savings from all regions and allocates investments so as to achieve equality of changes in expected future rates of return:

$$
\Delta \eta_{\mathrm{r}}=\Delta \eta
$$

where $\Delta \eta_{\mathrm{r}}$ and $\Delta \eta$ are the percentage change, respectively, in region's rate of return and global rate of return.

Every economy includes government interventions. Private households and the government not only spend their available income on consumption goods, but also 
pay taxes to the regional household. In the case of the government, taxes consist of consumption taxes on commodities. In the case of private household, taxes consist of consumption taxes and income tax net of subsidies. The firms have to pay taxes to the regional household. These value flows represent taxes on intermediate inputs and production taxes net of subsidies. Also trade generated tax revenues and subsidy expenditures are included in the GTAP model. All taxes levied in the economy always accrue to the regional household.

We introduce four refinements to the standard GTAP model in the AIDGEM model.

Firstly, we adopt the assumption of no full employment and a labour supply curve has been modelled, which specifies the relation between labor supply and the real wage:

$$
L=L^{S}\left(\frac{W}{P}\right)
$$

A description of modeling the labour supply function appears in the Appendix.

Secondly, as AfT policies implies that donors transfer income to the recipient countries, this element is inserted into the equation computing the national income as the total value of all domestic primary resources. Thus, let $\mathrm{AID}_{\mathrm{r}}$ be the AfT transfer in region $r$, the regional income is equal to:

$$
Y_{r}=\sum_{i=1}^{n} P_{i, r} E_{i, r}+T_{r}+A I D_{r}
$$

where $\mathrm{E}_{\mathrm{i}, \mathrm{r}}$ is the endowment $i$ and $\mathrm{P}_{\mathrm{i}, \mathrm{r}}$ is the market price of the endowment $\mathrm{i}, \mathrm{T}_{\mathrm{r}}$ are the tax revenues. The AfT transfer will increase (decrease) the regional income of the recipient (donor) country. To be consistent with general equilibrium conditions, the algebraic sum of all income transfers introduced in the model equations must be zero. This ensures that the redistribution of income is globally neutral and that income shocks have the same sign as demand shocks.

Thirdly, investment has been fixed exogenously such that the endogenous change of the capital goods demand, $\Delta K_{r}^{D}$, must be equal to the endogenous change of the capital goods output, $\Delta K_{r}^{S}$, and to the exogenous change of the regional investment, $\Delta I_{r}^{S}$. Thus, the following two equations must be satisfied to obtain the equilibrium for capital goods market:

$$
\begin{gathered}
\Delta K_{r}^{D}=\Delta K_{r}^{S} \\
\Delta K_{r}^{D}=\Delta I_{r}^{S}
\end{gathered}
$$

To ensure the equalization of global savings and investment, an endogenous adjustment of regional saving has been set up assuming that all regional investments increase by the same percentage. In this way, the assumption of perfect international mobility of capital is respected.

Finally, two representative international income inequality measures have been introduced: coefficient of variation and Atkinson's index. 
The coefficient of variation is calculated as the sum of income squared deviations:

$$
c=\frac{\sqrt{\frac{1}{n} \sum_{r=1}^{n}\left(y_{r}-\bar{y}\right)^{2}}}{\bar{y}}
$$

where $\bar{y}$ is the regional mean income. The procedure of forming the square places more weight on income that are further away from the mean.

The Atkinson's index is defined by

$$
A=1-\frac{M E D E}{\bar{y}}
$$

where MEDE is the equally distributed equivalent income.

These two measures of income inequality have been chosen with respect to others, because they respect all of the following properties: (a) weak principle of transfers; (b) scale independence; (c) principle of population; (d) decomposability. The income inequality measures are summary indices, that are explained within the model and their values are endogenously changed (determined).

\section{Data Source and Model Calibration}

In the CGE models, a set of mathematic equations translates the structure of an economy and describes the behaviour of all agents and the equilibrium conditions of all markets. A calibration procedure fixes the parameters for the model's equations (called benchmark equilibrium) and, then the model can be solved for an alternative scenario associated with any changed policy regime. A comparison between the counterpart or comparative scenario and the benchmark scenario makes it possible to assess effects on allocation and income distribution. CGE model is designed to analyze "What if" question. For example, what is the impact of foreign aid (\$1000 million US dollars) on recipient country's income, output, welfare and other key economic indicators? The second advantage of CGE model is that it catches the sectoral and regional linkage effects. While partial equilibrium model are unable to provide the overview of the counterpart scenarios.

The AIDCGEM model is calibrated for the year 2001 using the GTAP data base, version 6 and foreign aid data is mainly extracted from OECD STAT. ${ }^{2}$

GTAP data base, around which the model has been built, is a cross-section data of international trade flows and national input-output tables. All the information in the data base is reported in values converted to US dollars.

The behavioral parameters of the GTAP model and their estimates included in the GTAP data base are described in Dimaran (2006). In particular, there are five sets of behavioral parameters in GTAP data base: (i) the source substitution or Armington elasticities; (ii) the factor substitution elasticities; (iii) the factor

\footnotetext{
${ }^{2}$ Foreign aid data set is extracted from OECD STAT

(Available at http://www.oecd.org/document/21/0,3746,en_2649_34665_43230357_1_1_1_ 1,00.html)
} 
transformation elasticities; (iv) the investment parameters; $(v)$ the consumer demand elasticities.

The GTAP data base includes two types of source substitution elasticities. Firstly, substitution elasticities between domestic products and imports, which are defined separately for each of the representative agents within each region. This means that for each commodity within each region, the domestic-import mix is determined separately for each industry and for each of the final demand categories (investment, household and government consumption). Secondly, the substitution elasticities between imports from different regions, which is determined separately for intermediate usage (for all industries together) and for each of the final demand category. For each commodity the substitution elasticity is assumed to be the same for all agents in all regions. Primary factors of production are assumed to substitute for one another according to the constant elasticity of substitution, while composite value-added and intermediates are used in fixed proportions.

The third class of behavioral parameters in GTAP describes the degree of primary factor mobility between the sectors. Within each region, the model distinguishes between primary factors that are perfectly mobile across productive sectors and those that are sluggish. If the factor transformation elasticity is close to zero, then the allocation of factors across sectors is nearly fixed, and therefore factor supply is unresponsive to changes in relative returns. As it takes on larger negative values, then the supply of factors will become more and more responsive to relative returns.

Fourthly, investment flexibility parameters refer to the degree of flexibility of regional investment. The smaller the value of this parameter, the greater the responsiveness of international investment to a change in the rate of return in region $r$.

Finally, as the GTAP model employs the constant difference of elasticities (CDE) functional form in the specification of private household demand, the GTAP data base includes income and compensated own-price elasticities of demand.

The GTAP data base, version 6, includes 87 regions and 57 commodities. For our analysis, the regions are aggregated from 87 regions to 16 regions. The regional aggregation has been selected primarily based on importance in the world production, consumption, international trade, economic development and geographic location. Thus, the regional aggregation includes five donor countries and eleven recipient countries (Table 1).

As the GTAP 6 data base contains data for 2001, but the AfT policies is designed for the year 2010, we follow the methodology described in Arndt et al. (1997) to provide a status quo projection of the global economy in the selected year. The approach is based on a two-stage procedure. Firstly, we have generated "pseudo-calibration" from 2001 to 2010 by calibrating the technical parameters related to population growth, capital and labour stock change, labour and land productivity change, so that we achieve growth in regional GDP consistent with the World Bank projections. Figure 2 shows the convergence results to the real data in terms of GDP. The resulting scenario in this first stage is called "baseline". Subsequently, conventional comparative analysis is conducted simulating the AfT scenarios for 2010. 
Table 1 Regional aggregation

\begin{tabular}{|c|c|c|}
\hline Acronym & Region & Type \\
\hline USA & United States & Donor \\
\hline CAN & Canada & Donor \\
\hline WEU & $\begin{array}{l}\text { Western Europe (Austria, Belgium, Denmark, Finland, France, Germany, Greece, } \\
\text { Iceland, Ireland, Italy, Liechtenstein, Luxembourg, the Netherlands, Norway, } \\
\text { Portugal, Spain, Sweden, Switzerland, the United Kingdom) }\end{array}$ & Donor \\
\hline JPK & Japan and South Korea & Donor \\
\hline ANZ & Australia, New Zealand and Oceania & Donor \\
\hline EEU & $\begin{array}{l}\text { Eastern Europe (Bulgaria, Cyprus, Czech Republic, Estonia, Hungary, Latvia, } \\
\text { Lithunia, Malta, Poland, Romania, Slovakia, Slovenia) }\end{array}$ & Recipient \\
\hline FSU & Former Soviet Union & Recipient \\
\hline MDE & Middle East (Turkey, Rest of Middle East) & Recipient \\
\hline CAM & Central America (Mexico, Central America, Carribean) & Recipient \\
\hline SAM & $\begin{array}{l}\text { South America (Colombia, Perù, Venezuela, Rest of Andean Pact, Argentina, } \\
\text { Brazil, Chile, Uruguay, Rest of South America) }\end{array}$ & Recipient \\
\hline SAS & South Asia (Bangladesh, India, Sri Lanka, Rest of South Asia) & Recipient \\
\hline SEA & $\begin{array}{l}\text { Southeast Asia (Taiwan, Indonesia, Malaysia, Philippines, Singapore, Thailand, } \\
\text { Vietnam) }\end{array}$ & Recipient \\
\hline $\mathrm{CHI}$ & China (China, Hong Kong) & Recipient \\
\hline NAF & North Africa (Morocco, Rest of North Africa) & Recipient \\
\hline SSA & $\begin{array}{l}\text { Sub-Saharan Africa (Botswana, Rest of SACU, Malawi, Mozambique, Tanzania, } \\
\text { Zambia, Zimbabwe, Other Southern Africa, Uganda, Rest of Sub-Saharan Africa) }\end{array}$ & Recipient \\
\hline ROW & Rest of the world & Recipient \\
\hline
\end{tabular}

Authors' modelling aggregation based on GTAP data base

\section{Modeling Policy Scenarios}

In this section we present four policy scenarios, which have been constructed such that to include the AfT categories identified by the Task Force on Aid for Trade

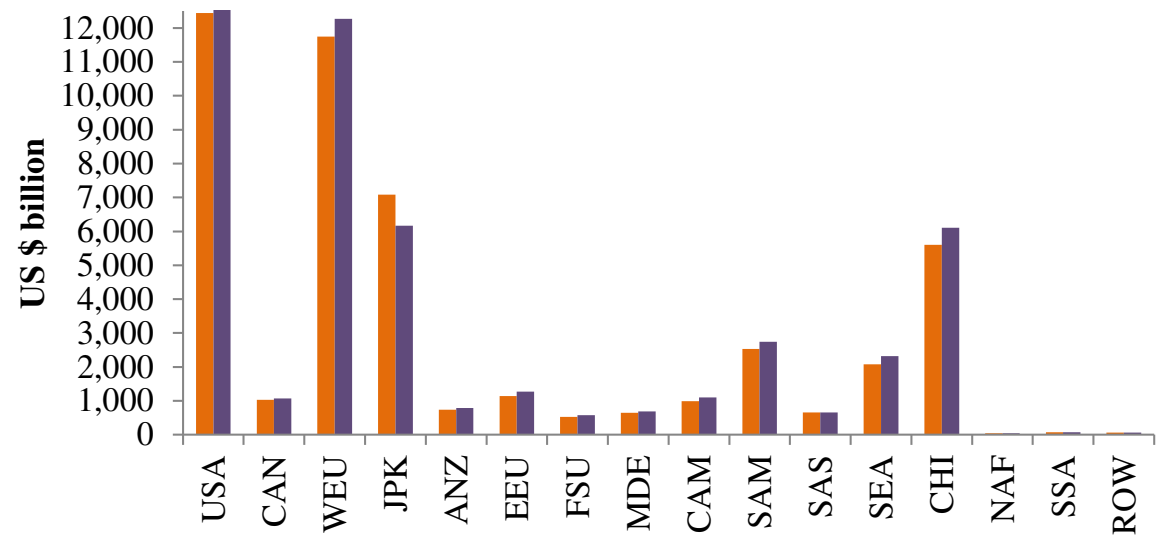

- Model Baseline Calibration $₫$ World Bank World Development Indicators Data

Fig. 2 Gross domestic product (GDP) convergence. Source: Our calculation from World Development Indicators \& authors' modeling results 
(WTO 2006). The AfT policy scenarios are carried out as comparative static analysis in variables that are exogenous in the closure of the model. Table 2 reports the description of the policy scenarios.

The first scenario, called "trade adjustment assistance", involves fiscal support and policy advice to help countries cope with any transitional adjustment costs from liberalization. This scenario implies an income transfer from the donors to the recipient countries. The exogenous shocked variable in the AIDCGEM is the AfT transfer $\left(\mathrm{AID}_{\mathrm{r}}\right)$ in region $r$. The AfT transfer is not constrained, that is, it is not related to any project or public expenditure in the recipient countries. The aid for trade data comes from OECD.STAT data base. The amount of aid for trade is equal to the $25 \%$ of the Official Development Assistance (ODA). Table 3 reports the AfT distribution applied in each scenario.

In the other three scenarios, the amount of AfT transfer is unchanged with respect to the first scenario, but the AfT is now constrained for the recipient countries. In fact, the second scenario, called "institutional reforms", is designed to reduce transaction costs and introduce quality assurance such that the demand for exports expands. This is simulated through an AfT transfer by donors countries which reduces their income. This income transfer is used to reduce the export tax revenues for the recipient countries. The third scenarios, called "technical assistance and capacity building", aims to improve the productivity of factors, through supplying training and awareness of production process. This is simulated by an AfT transfer by donors countries which reduces their income and by using this income transfer for augmenting the productivity for all factors in the recipient countries. The fourth scenario, called "Infrastructure", involves infrastructure improvements, widespread throughout the economy. This is simulated by an AfT transfer by donors countries, which reduces their income and by using this income for increasing investment in the

Table 2 Scenario design and instrument description

\begin{tabular}{|c|c|c|}
\hline Scenario & $\begin{array}{l}\text { AfT policy intervention } \\
\text { for the recipient countries }\end{array}$ & AfT policy impacts \\
\hline $\begin{array}{l}\text { 1. Trade adjustment } \\
\text { assistance(TAA) }\end{array}$ & Increase in the aid budget & $\begin{array}{l}\text { - Donor countries: negative Income transfer } \\
\text { - Recipient countries: Unconstrained } \\
\text { positive income transfer }\end{array}$ \\
\hline $\begin{array}{l}\text { 2. Institutional } \\
\text { reform (IR) }\end{array}$ & $\begin{array}{l}\text { Reduce transaction costs \& introduce } \\
\text { quality assurance }\end{array}$ & $\begin{array}{l}\text { - Donor countries: Negative Income transfer } \\
\text { - Recipient countries: Constrained positive } \\
\text { income transfer for reducing export tax }\end{array}$ \\
\hline $\begin{array}{l}\text { 3. Technical } \\
\text { assistance \& } \\
\text { capacity building } \\
\text { (TA \&CB) }\end{array}$ & $\begin{array}{l}\text { Update the production processes, } \\
\text { access market information and } \\
\text { improve efficiency }\end{array}$ & $\begin{array}{l}\text { - Donor countries: Negative Income transfer } \\
\text { - Recipient countries: Constrained positive } \\
\text { income transfer for raising efficiency } \\
\text { for all factors }\end{array}$ \\
\hline $\begin{array}{l}\text { 4. Economic } \\
\text { infrastructure }\end{array}$ & Improve infrastructure & $\begin{array}{l}\text { - Donor countries: Negative Income transfer } \\
\text { - Recipient countries: Constrained positive } \\
\text { income transfer for raising investments }\end{array}$ \\
\hline
\end{tabular}


Table 3 Aid for trade distribution

\begin{tabular}{lc}
\hline Donor & Income transfer (US \$ million change w.r.t. baseline scenario) \\
\hline United States & -3998.94 \\
Canada & -3617.13 \\
Western Europe & -4240.08 \\
Japan & -4300.37 \\
Australia, New Zealand \& Oceania & -3938.65 \\
Recipient & \\
Eastern Europe & 742.63 \\
Former Soviet Union & 342.94 \\
Middle East & 3271.26 \\
Central America & 1606.96 \\
South America & 1635.11 \\
South Asia & 2959.25 \\
Southeast Asia & 1684.83 \\
Mainland China & 482.96 \\
North Africa & 492.5 \\
Sub-Saharan Africa & 6209.75 \\
Rest of the world & 667 \\
\hline
\end{tabular}

Authors'calculation based on OECD.STAT and GTAP data base

recipient countries. Table 4 reports the details of the shocks applied in these three scenarios in the recipient countries. The shocks in terms of AfT transfer for the donor countries are unchanged and equal to those reported in Table 3.

Table 4 Effectiveness of aid for trade on different scenarios (w.r.t. baseline)

\begin{tabular}{llll}
\hline Region/Country & $\begin{array}{l}\text { Institutional reform } \\
\text { (IR) scenario: } \\
\text { Export tax revenues } \\
\text { (US \$ million) }\end{array}$ & $\begin{array}{l}\text { Technical assistance \& } \\
\text { capacity building scenario: } \\
\text { Factor productivity (\%) }\end{array}$ & $\begin{array}{l}\text { Economic infrastructure } \\
\text { scenario: } \\
\text { Investment (\%) }\end{array}$ \\
\hline Eastern Europe & -3.85 & 0.08 & 0.05 \\
Former Soviet Union & -342.94 & 0.08 & 0.09 \\
Middle East & -1408.37 & 0.63 & 0.74 \\
Central America & -1273.37 & 0.19 & 0.21 \\
South America & -1635.11 & 0.07 & 0.07 \\
South Asia & -2959.25 & 0.61 & 0.54 \\
Southeast Asia & -1684.83 & 0.09 & 0.07 \\
China & -482.96 & 0.01 & 0 \\
North Africa & -492.5 & 1.29 & 1.11 \\
Sub-Saharan Africa & -0.06 & 10.2 & 12.43 \\
Rest of the world & -34.24 & 1.26 & 1.53 \\
\hline
\end{tabular}

Author's calculations based on OECD.STAT and GTAP data base 


\section{Modeling Results}

Effectiveness requires that AfT policy achieves its stated goals. Following the WTO/OECD report (WTO/OECD 2011), the common priorities between donor and recipient countries are to expand trade and, jointly, to alleviate inequalities. We use trade balance, computed as total exports less total imports as trade indicator; whereas, welfare and income indicators are employed to evaluate inequalities. We compute the equivalent variation as money metric measure of economic welfare. Income is defined as the service value of national primary factors, which are in the AIDCGEM model natural resources, land, labor and capital. Furthermore, the coefficient of variation and the Atkinson index, computed respectively as defined in Eqs. (8) and (9), have been used for the analysis of international income inequality.

In terms of trade, Fig. 3 shows that China (CHI) substantially gains from the institutional reform scenario; almost all the other countries have moderate gains with the technical assistance and capacity building scenario.

Usually, the effects on trade balance yield opposite effects on welfare. In other words, trade adjustment assistance reduce transaction cost of almost all countries or regions (except China) compared with its base line value. China's trade surplus is big enough to offset the transaction cost. Trade adjustment assistance scenario yields the highest positive effects on welfare scenario for almost all the countries (Fig. 4). East Europe, Asian and African countries mainly benefit from technical assistance and capacity building scenario. The welfare effects slightly differ between trade adjustment and technical assistance scenarios for Central and South America. The magnitude of trade and welfare effects may differ, due to the fact, that the effects on welfare

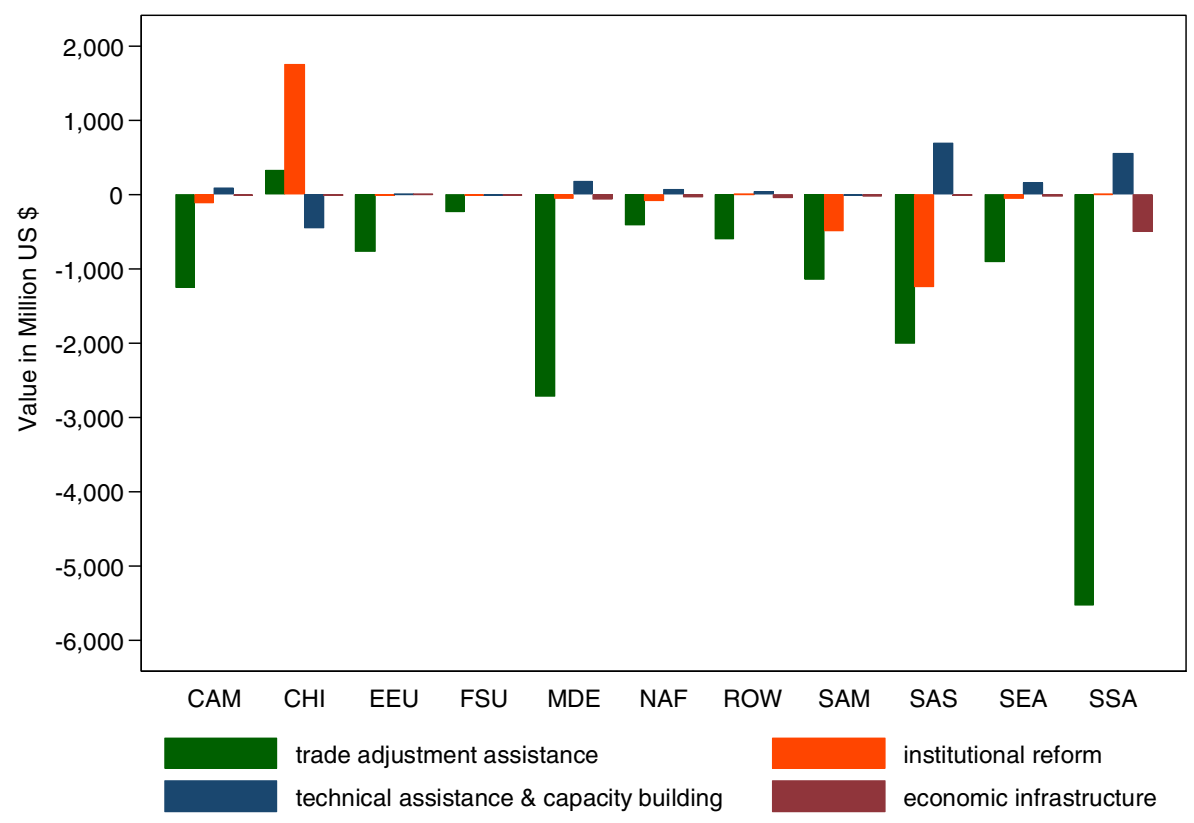

Fig. 3 Trade balance (change w.r.t baseline scenario). Source: Authors' modeling results; Note: Trade balance $=$ Exports-Imports 


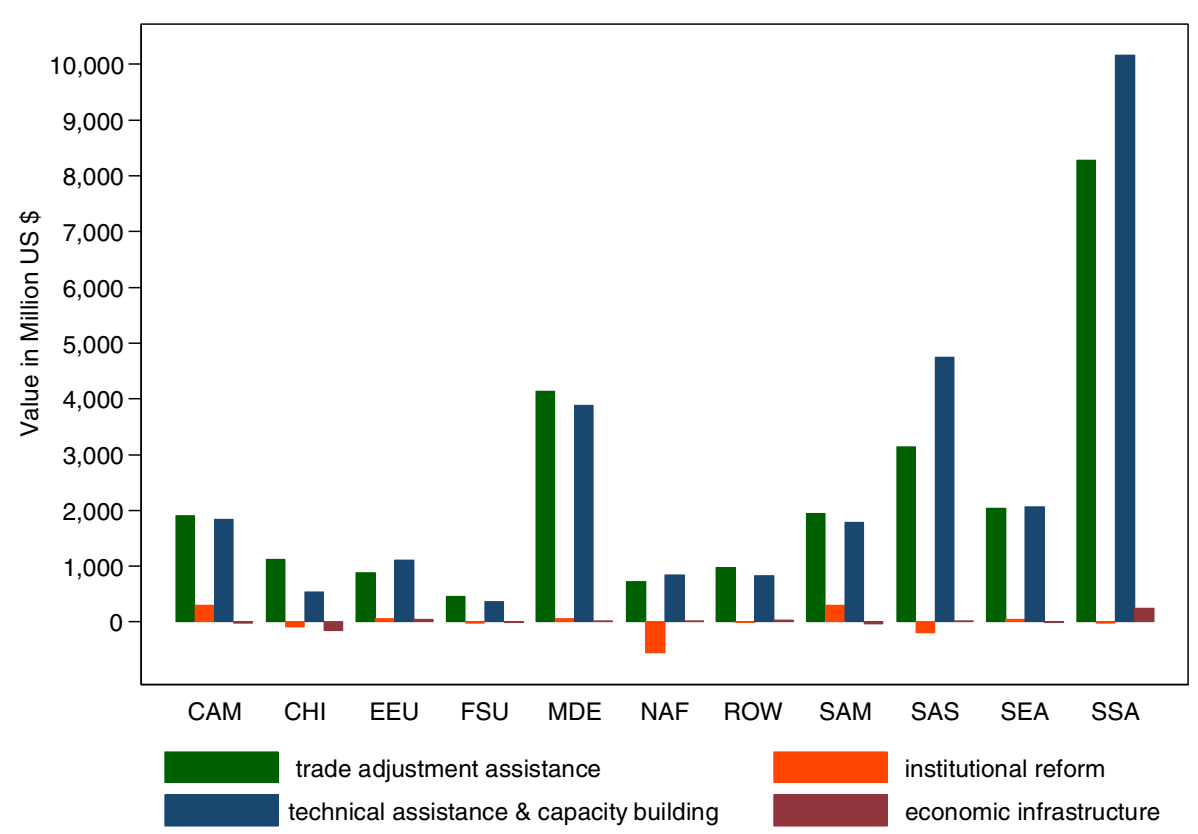

Fig. 4 Welfare effects (change w.r.t baseline scenario). Source: Authors' modeling results

change are not limited to terms of trade, but include endowment, technical efficiency, allocative efficiency and income contributions. In fact, if on the one hand, technical assistance and capacity building scenario have positive trade effects for South Asia (SAS) and Sub-Saharan Africa (SSA); on the other hand, they yield high positive effects on welfare, because the negative contribution to welfare change in terms of trade is compensated by the high positive contribution to welfare change of allocative effects. The welfare effects of the other two scenarios (institutional reform and economic infrastructure) are very small. The results in terms of welfare are reported in Fig. 4.

The effects on income per capita are mainly positive, but very small, except for Sub-Saharan Africa (SSA), that has substantial positive change in the trade adjustment assistance and technical assistance and capacity building scenarios (Fig. 5). This result is due to the fact that the Sub-Saharan African countries receive the significant amount of aid for trade, that yields high income and allocative effects on welfare change. The trade adjustment assistance scenario yields the highest positive change in the income per capita for all the countries.

Table 5 reports the most preferred scenario per indicator for every recipient country or region. A combination of the adjustment trade assistance and technical assistance and capacity building scenarios would guarantee the effectiveness more than the other scenarios for almost all the countries. A combination of the trade adjustment assistance and institutional reform policy actions will be more effective in China. For the Former Soviet Union the trade adjustment assistance policy should be coupled with public policies aimed to increase investments. For the East European countries the ranking of scenarios differs amongst indicators. In fact, these countries would gain from the economic infrastructure scenario in terms of trade, from the 


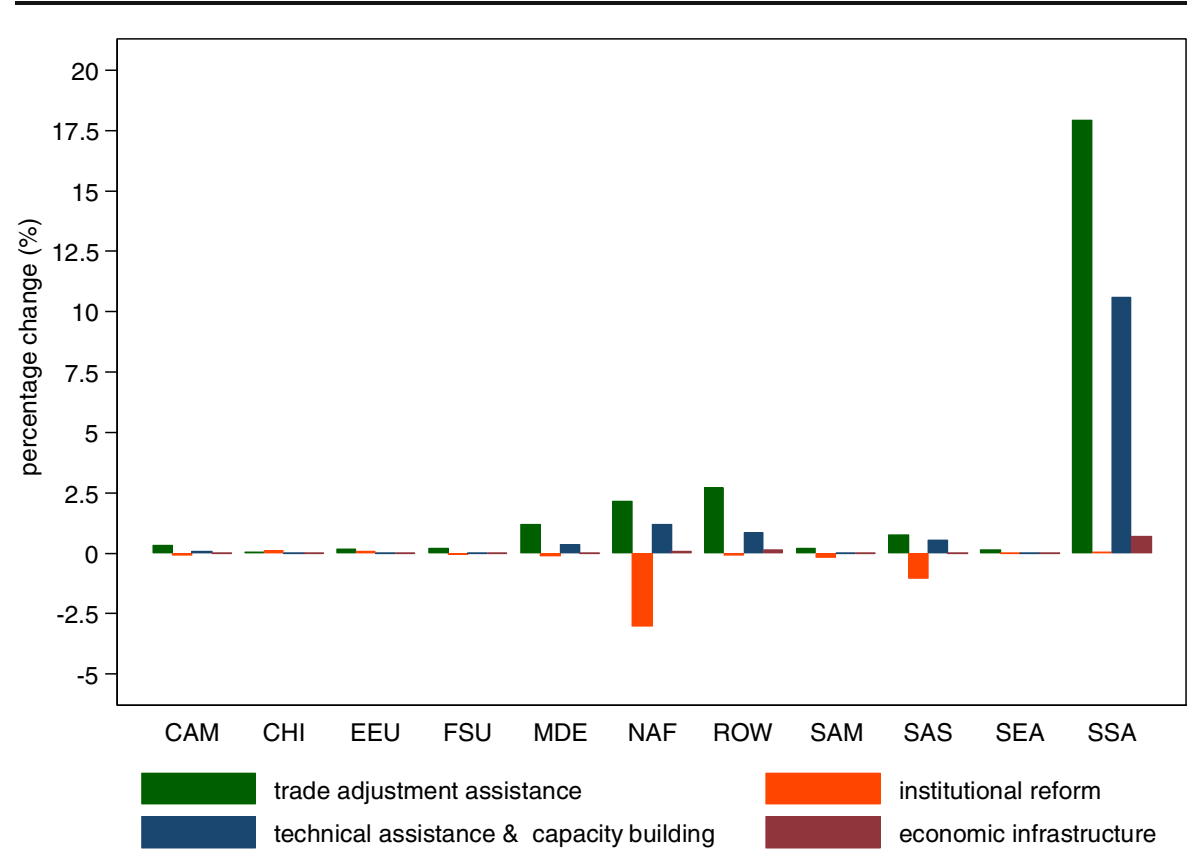

Fig. 5 Income per capita (change w.r.t baseline scenario). Source: Authors' modeling results

technical assistance and capacity building scenarios in terms of welfare and from the trade adjustment assistance scenario in terms of income per capita.

Furthermore, preferences for trade adjustment assistance (TAA) and technical assistance and capacity building (TA \& CB) scenarios are enforced at international level. In both these scenarios, the international income inequalities, which computed by the

Table 5 Scenario ranking in terms of effectiveness for each aid receipting Countries or Regions*

\begin{tabular}{llll}
\hline Region & Trade balance & Welfare & Income per capita \\
\hline Eastern Europe & EI & TA \& CB & TAA \\
Former Soviet Union & EI & TAA & TAA \\
Middle East & TA \& CB & TAA & TAA \\
Central America & TA \& CB & TAA & TAA \\
South America & TA \& CB & TAA & TAA \\
South Asia & TA \& CB & TA \& CB & TAA \\
Southeast Asia & TA \& CB & TAA & TAA \\
China & IR & TAA & TAA \\
North Africa & TA \& CB & TA \& CB & TAA \\
Sub-Saharan Africa & TA \& CB & TA \& CB & TAA \\
Rest of the world & TA \& CB & TAA & IR \\
\hline
\end{tabular}

Modeling results based on OECD.STAT and GTAP data base

*TA \& $C B$ stands for technical assistance and capacity building, TAA stands for Trade Adjustment assistance, $I R$ stands for institutional reform, $E I$ stands for Economic Infrastructure 
coefficient variation and the Atkinson's index, decrease implying that AfT effectiveness occurs in redistributing income from the richest to the low income countries. The opposite effect occurs for the institutional reform and infrastructure scenarios (Fig. 6).

\section{Sensitivity Analysis}

In order to test under which conditions the scenario ranking is robust to changes in parameters, we apply the unconditional systematic sensitivity analysis (USSA) as proposed by Harrison and Vinod (1992), in which a random sample of all the possible parameter combinations is analyzed.

In more details, the method has involved the specification of a certain number of experiments, which set different possible parameter combinations. The parameter $n_{i}$ has been supposed to evolve according to the stochastic differential equation:

$$
d n_{i}=\mu n_{i} d t+\sigma n_{i} d z \quad \forall i
$$

This equation implies that $n_{i}$ is changing according to a process of geometric Brownian motion (GBM). The term $\mu d t$ is the mean or expected percentage change in $n_{i}$ for the increment $d t$, and $\mu$ is called the mean drift rate. The term $\sigma d z$ introduces a random component to the drift, because $d z=\varepsilon(t) \sqrt{d t}$, where $\varepsilon(t)$ is a random variable.

We have generated sample paths of 100 random numbers for the following parameters: elasticity of substitution of input production factors (capital, labor and land), region-generic elasticity of substitution among imports in Armington structure,

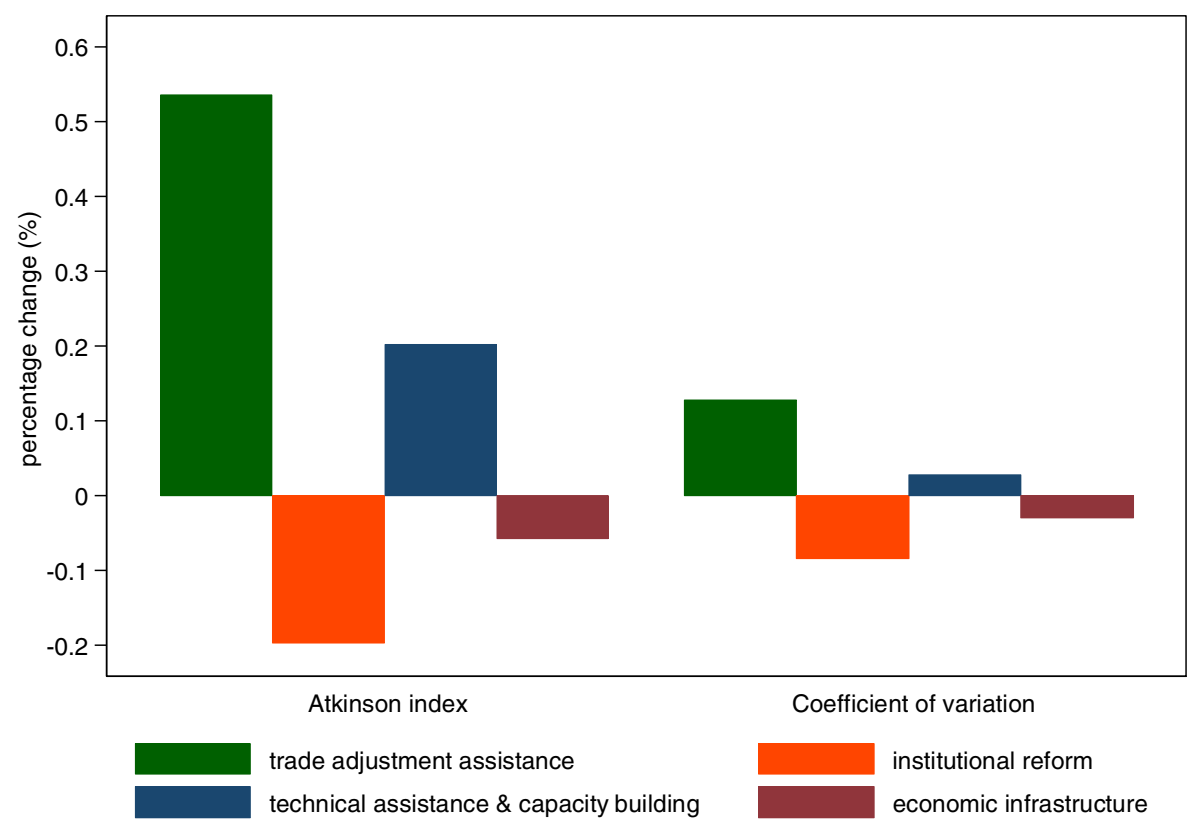

Fig. 6 International income inequality index (change with respect to benchmark scenario). Source: Authors' modeling results 
region-generic elasticity of substitution between domestic and imports in Armington structure. Each parameter is assumed to follow a univariate uniform distribution.

The results of the sensitivity analysis reported in Table 6 confirm the scenario ranking. Technical assistance and capacity building is the most preferred scenario in terms of trade, except for China and Eastern Europe, that benefit, respectively, from institutional reform and economic infrastructure scenarios. Trade adjustment assistance is the most preferred scenario in terms of income distribution. In terms of welfare, technical assistance and capacity building scenario is the most preferred by East Europe, Asian and African countries. China, Middle East and Former Soviet Union benefit from the trade adjustment assistance scenario. Central and South America change their scenario ranking from the trade adjustment assistance to the technical assistance and capacity building scenario as the parameter values increase. This finding is due to the fact that the welfare effects of these two scenarios slightly differ in these countries.

Furthermore, we apply the USSA, described above to the shocks values reported in Tables 3 and 4 in order to test if the results are robust. Thus, we have generated sample paths of 100 random numbers for the shock values (which are again assumed to follow a univariate uniform distribution) in the selected scenario. Our findings show that the scenario ranking is robust to shock changes (Table 7).

\section{Conclusions}

Recent global initiatives on debt relief and development assistance call for increasing foreign aid to the poorest countries. This has been reflected by the amount of aid that has been expanded over decades despite of recent global financial crisis (WTO/OECD 2011). In particular, in 2005 at Hong Kong WTO Ministerial Conference, aid for trade have been launched that provide financial and technical assistance to facilitate the integration of low-income countries into the global economy.

So far, as there is no quantitative study that analyzes the Aft policy impacts, especially at aggregated regional level, using a multi-country computable general equilibrium model, this paper attempts to provide a global perspective on effectiveness of AfT. We use three indicators (trade balance, welfare and income) to measure AfT effectiveness. Our findings show that AfT policies expand trade, welfare and income in the recipient countries. The policy implications of this paper suggest that the effectiveness of AfT policies varies by instruments and by region. Generally, the scenario ranking shows that trade adjustment and technical assistance will be the critical challenges for achieving the objectives of AfT policy.

The uneven distribution of the AfT policy effects on different regions may depend on the relationship between trade and income inequality in these regions. However, the question of whether trade policy would have positive effects on income inequality is still under debate. Some economists find negative effects and/or no effects of trade policy on income inequality (Krishna and Guru 2011; Morrissey et al. 2002a, b). Meschi and Vivarelli (2007) find that trade with high income countries worsen income distribution in developing countries. Furthermore, the effectiveness of AfT programme is strongly dependent to the presence or absence of institutions in the recipient 
Table 6 Sensitivity analysis of parameter values (change w.r.t. baseline scenario)

\begin{tabular}{|c|c|c|c|c|c|c|c|c|}
\hline \multirow[b]{2}{*}{$\begin{array}{l}\text { Welfare change } \\
\text { (Million US \$) }\end{array}$} & \multicolumn{2}{|c|}{ Scenario 1: TAA* } & \multicolumn{2}{|c|}{ Scenario 2: IR* } & \multicolumn{2}{|c|}{ Scenario 3: TA\&CB* } & \multicolumn{2}{|c|}{ Scenario 4: EI* } \\
\hline & Min & Max & Min & Max & Min & Max & Min & Max \\
\hline \multicolumn{9}{|l|}{ Region } \\
\hline Eastern Europe & 880 & 844 & 61 & 32 & 1100 & 1036 & 38 & 22 \\
\hline Former Soviet Union & 453 & 405 & -28 & -68 & 363 & 399 & -9 & -6 \\
\hline Middle East & 4105 & 3816 & 54 & 14 & 3898 & 4115 & 4 & 7 \\
\hline Central America & 1896 & 1776 & 284 & 55 & 1839 & 1900 & -16 & -7 \\
\hline South America & 1930 & 1814 & 272 & -134 & 1782 & 1826 & -31 & -14 \\
\hline South Asia & 3123 & 3051 & -311 & -1364 & 4770 & 4910 & 8 & 8 \\
\hline Southeast Asia & 2024 & 1860 & 23 & -164 & 2070 & 2138 & -8 & 4 \\
\hline China & 1089 & 740 & -72 & -6 & 540 & 651 & -160 & -66 \\
\hline North Africa & 719 & 652 & -614 & -1036 & 857 & 1058 & 20 & 14 \\
\hline Sub-Saharan Africa & 8211 & 7574 & -24 & -24 & 10354 & 12681 & 237 & 171 \\
\hline Rest of the world & 967 & 860 & -16 & -27 & 834 & 899 & 29 & 19 \\
\hline $\begin{array}{l}\text { Trade balance } \\
\quad \text { (Million US \$) }\end{array}$ & Min & Max & Min & Max & Min & Max & Min & Max \\
\hline \multicolumn{9}{|l|}{ Region } \\
\hline Eastern Europe & -773 & -765 & -17 & -16 & -3 & -4 & -2 & -1 \\
\hline Former Soviet Union & -227 & -264 & -23 & -32 & -13 & 5 & -9 & -8 \\
\hline Middle East & -2723 & -2858 & -63 & -71 & 182 & 243 & -72 & -72 \\
\hline Central America & -1267 & -1343 & -124 & -160 & 90 & 125 & -19 & -13 \\
\hline South America & -1153 & -1303 & -498 & -589 & -17 & 24 & -29 & -17 \\
\hline South Asia & -2030 & -2193 & -1293 & -1531 & 703 & 806 & -19 & -19 \\
\hline Southeast Asia & -908 & -1053 & -76 & -148 & 165 & 243 & -27 & -13 \\
\hline China & 299 & -23 & 1779 & 1706 & -467 & -526 & -22 & -2 \\
\hline North Africa & -411 & -422 & -96 & -140 & 72 & 96 & -39 & -39 \\
\hline Sub-Saharan Africa & -5541 & -5660 & -1 & -1 & 568 & 743 & -507 & -514 \\
\hline Rest of the world & -602 & -613 & -2 & -3 & 42 & 48 & -54 & -55 \\
\hline $\begin{array}{l}\text { Income per capita } \\
(\%)\end{array}$ & Min & Max & Min & Max & Min & Max & Min & Max \\
\hline \multicolumn{9}{|l|}{ Region } \\
\hline Eastern Europe & 0.161 & 0.117 & 0.088 & 0.082 & 0.019 & 0.025 & 0.002 & 0.002 \\
\hline Former Soviet Union & 0.202 & 0.137 & -0.038 & -0.054 & -0.028 & 0.003 & -0.005 & -0.003 \\
\hline Middle East & 1.180 & 0.877 & -0.136 & -0.152 & 0.355 & 0.489 & 0.002 & 0.002 \\
\hline Central America & 0.316 & 0.244 & -0.116 & -0.150 & 0.080 & 0.113 & -0.011 & -0.005 \\
\hline South America & 0.196 & 0.134 & -0.205 & -0.242 & -0.010 & 0.007 & -0.009 & -0.004 \\
\hline South Asia & 0.745 & 0.612 & -1.080 & -1.271 & 0.550 & 0.634 & 0.002 & 0.002 \\
\hline Southeast Asia & 0.135 & 0.109 & -0.012 & -0.025 & 0.027 & 0.040 & -0.004 & -0.001 \\
\hline China & 0.045 & 0.026 & 0.102 & 0.098 & -0.027 & -0.030 & -0.001 & 0.000 \\
\hline North Africa & 2.121 & 1.733 & -3.183 & -4.251 & 1.252 & 1.919 & 0.080 & 0.051 \\
\hline Sub-Saharan Africa & 17.511 & 13.773 & 0.036 & 0.036 & 11.014 & 15.738 & 0.677 & 0.422 \\
\hline Rest of the world & 2.630 & 1.978 & -0.118 & -0.147 & 0.894 & 1.220 & 0.127 & 0.073 \\
\hline
\end{tabular}

Authors'USSA results

*TA \& $C B$ stands for technical assistance and capacity building, TAA stands for Trade Adjustment assistance, $I R$ stands for institutional reform, $E I$ stands for Economic Infrastructure 
Table 7 Sensitivity analysis of shocks values (change w.r.t. baseline scenario)

\begin{tabular}{|c|c|c|c|c|c|c|c|c|}
\hline \multirow[b]{2}{*}{$\begin{array}{l}\text { Welfare change } \\
\text { (Million US \$) }\end{array}$} & \multicolumn{2}{|c|}{ Scenario 1: TAA* } & \multicolumn{2}{|c|}{ Scenario 2: IR* } & \multicolumn{2}{|c|}{ Scenario 3: TA\&CB* } & \multicolumn{2}{|c|}{ Scenario 4: EI* } \\
\hline & Min & Max & Min & Max & Min & Max & Min & Max \\
\hline \multicolumn{9}{|l|}{ Region } \\
\hline Eastern Europe & 899 & 1776 & 68 & 99 & 1106 & 2186 & 40 & 79 \\
\hline Former Soviet Union & 462 & 913 & -29 & 220 & 360 & 714 & -10 & -19 \\
\hline Middle East & 4181 & 8231 & 61 & 315 & 3889 & 7691 & 4 & 8 \\
\hline Central America & 1933 & 3817 & 319 & -105 & 1835 & 3628 & -16 & -32 \\
\hline South America & 1967 & 3887 & 300 & -180 & 1781 & 3521 & -32 & -63 \\
\hline South Asia & 3180 & 6264 & -229 & 39 & 4754 & 9400 & 8 & 16 \\
\hline Southeast Asia & 2064 & 4081 & 88 & -124 & 2066 & 4082 & -8 & -15 \\
\hline China & 1132 & 2264 & -28 & -9452 & 538 & 1050 & -166 & -327 \\
\hline North Africa & 735 & 1448 & -598 & 130 & 841 & 1669 & 21 & 41 \\
\hline Sub-Saharan Africa & 8377 & 16140 & -28 & 112 & 10177 & 20316 & 246 & 488 \\
\hline Rest of the world & 991 & 1946 & -16 & 99 & 828 & 1639 & 31 & 61 \\
\hline $\begin{array}{l}\text { Trade balance } \\
\quad \text { (Million US \$) }\end{array}$ & Min & Max & Min & Max & Min & Max & Min & Max \\
\hline \multicolumn{9}{|l|}{ Region } \\
\hline Eastern Europe & -784 & -1548 & -19 & -2 & -3 & -5 & -2 & -3 \\
\hline Former Soviet Union & -227 & -450 & -25 & 93 & -14 & -27 & -9 & -18 \\
\hline Middle East & -2745 & -5419 & -67 & 100 & 178 & 351 & -72 & -143 \\
\hline Central America & -1274 & -2517 & -119 & -77 & 87 & 171 & -20 & -40 \\
\hline South America & -1152 & -2278 & -494 & 259 & -20 & -41 & -29 & -59 \\
\hline South Asia & -2033 & -4013 & -1372 & -120 & 690 & 1363 & -19 & -37 \\
\hline Southeast Asia & -908 & -1802 & -166 & 248 & 159 & 310 & -27 & -54 \\
\hline China & 326 & 645 & 1954 & 1279 & -447 & -908 & -15 & -35 \\
\hline North Africa & -415 & -819 & -95 & 14 & 70 & 138 & -39 & -76 \\
\hline Sub-Saharan Africa & -5598 & -11024 & -2 & 11 & 553 & 1085 & -511 & -1010 \\
\hline Rest of the world & -609 & -1202 & -2 & 8 & 41 & 81 & -55 & -108 \\
\hline $\begin{array}{l}\text { Income per capita } \\
(\%)\end{array}$ & Min & Max & Min & Max & Min & Max & Min & $\operatorname{Max}$ \\
\hline \multicolumn{9}{|l|}{ Region } \\
\hline Eastern Europe & 0.168 & 0.329 & 0.097 & 0.014 & 0.019 & 0.037 & 0.003 & 0.006 \\
\hline Former Soviet Union & 0.210 & 0.413 & -0.041 & 0.156 & -0.030 & -0.059 & -0.005 & -0.010 \\
\hline Middle East & 1.222 & 2.417 & -0.143 & 0.212 & 0.345 & 0.681 & 0.002 & 0.003 \\
\hline Central America & 0.328 & 0.646 & -0.111 & -0.076 & 0.077 & 0.152 & -0.012 & -0.024 \\
\hline South America & 0.205 & 0.403 & -0.203 & 0.105 & -0.011 & -0.023 & -0.009 & -0.018 \\
\hline South Asia & 0.773 & 1.528 & -1.147 & -0.098 & 0.540 & 1.066 & 0.002 & 0.004 \\
\hline Southeast Asia & 0.139 & 0.272 & -0.028 & 0.040 & 0.026 & 0.050 & -0.004 & -0.008 \\
\hline China & 0.047 & 0.092 & 0.112 & 0.075 & -0.026 & -0.052 & -0.001 & -0.002 \\
\hline North Africa & 2.187 & 4.326 & -3.173 & 0.336 & 1.197 & 2.369 & 0.085 & 0.167 \\
\hline Sub-Saharan Africa & 18.157 & 36.566 & 0.033 & 0.242 & 10.596 & 20.965 & 0.713 & 1.414 \\
\hline Rest of the world & 2.733 & 5.421 & -0.117 & 0.306 & 0.862 & 1.705 & 0.134 & 0.265 \\
\hline
\end{tabular}

Authors' USSA results

*TA \& $C B$ stands for technical assistance and capacity building, TAA stands for Trade Adjustment assistance, $I R$ stands for institutional reform, $E I$ stands for Economic Infrastructure 
countries. In fact, if on the on hand, high levels of aid have had the potential to improve governance, for example, aid has improved civil service, enforced social spending (specifically health, education and sanitation) and established strong central institutions, in countries with an aid agenda reform, such as South Asian countries; on the other hand, in countries with economic decline, political instability, corruption and without an aid reform agenda, such as the African countries, higher aid levels are associated with larger declines in the quality of governance and lower social spending (Bräutigam and Knack 2004; Morrissey 2010).

The AfT distribution needs to become more selective and competitive and in ways that reinforce a virtuous cycle of development in the recipient countries and enhance fiscal effectiveness.

Acknowledgments We are grateful to Peter J. Minor, John Wilson and Celestin Monga for helpful discussions and comments on an earlier draft. We also thank for insightful comments from conference host and participations of Aart Kraay, Daniel Kaufmann and the other economists at the World Bank Economist's Forum (April 18, 2011, Washington D.C. USA). We also received valuable comments from an anonymous referee. The views expressed in the paper are those of the authors, and should not be attributed to the World Bank, University of Palermo, their Executive Directors, or the countries they represent.

\section{Appendix}

Let $\mathrm{S}_{\mathrm{r}}$ be the labor supply, it is modeled as function of the real wage

$$
S_{r}=a_{r}-\frac{b_{r}}{w_{r}}
$$

where $a_{r}$ is an asymptote, which can be interpreted as the maximal potential amount of available unskilled labour force, and $b_{r}$ is a positive parameter. The labor supply elasticity in region $r, \varepsilon_{\mathrm{r}}$ in respect to the real wage, is equal to:

$$
\varepsilon_{r}=\frac{b_{r}}{a_{r} w_{r}-b_{r}}
$$

Given that the unemployment rate in region $r, u_{r}$, is equal to

$$
u_{r}=1-\frac{S_{r}}{a_{r}}
$$

the labour supply elasticity can be also expressed as function of the unemployment rate as follows:

$$
\varepsilon_{r}=\frac{u_{r}}{1-u_{r}}
$$

\section{References}

Anderson K, Strutt A (1996) On measuring the environmental impact of agricultural trade liberalisation. In: Bredahl ME, Ballenger N, Dunmore JC, Roe TL (eds) Agriculture, trade and the environment: discovering and measuring the critical linkages. Westview Press, Boulder 
Ang JB (2010) Does foreign aid promote growth? Exporting the role of financial liberalization? Rev Dev Econ 14(2):197-212

Armington PA (1969) A theory of demand for products distinguished by place of production. IMF Staff Pap 16:159-178

Arndt C, Hertel T, Dimaranan B, Huff K, McDougall R (1997) China in 2005: implications for the rest of the world. GTAP working paper. Centre of Global Trade Analysis, Purdue University

Balassa B (1978) Exports and economic growth: further evidence. J Dev Econ 5(2):181-189

Bauer PT (1975) N. H. Stern on substance and method in development economics. J Dev Econ (2):387-405

Bourguignon F, Sundberg M (2007) Is foreign aid helping? Aid effectiveness — opening the Black Box. Am Econ Rev 97(2)

Bräutigam DA, Knack S (2004) Foreign aid, institutions, and governance in Sub-Saharan Africa. Econ Dev Cult Chang 52(2):255-285

Burnside C, Dollar D (2000) Aid, policies, and growth. Am Econ Rev 90(4):847-868

Calì M, Velde DWT (2011) Does aid for trade really improve trade performance? World Dev 39:725-740

Cockburn J, Decaluwé B, Robichaud V (2005) Lessons from a CGE model on the impacts of trade liberalization on growth, poverty and inequality in seven Asian and African countries. Université Laval, Québec, Mimeo

Collier P, Dollar D (2002) Aid allocation and poverty reduction. Eur Econ Rev 45:1470-1500

Dalgaard C, Hansen H (2001) Aid, growth and good policies. J Dev Stud 37:17-41

Dimaran BV (2006) Global trade, assistance and application: the GTAP 6 data base. GTAP working paper. Center for Global Trade Analysis, Purdue University

Dollar D, Kraay A (2001) Growth is good for the poor. J Econ Growth 7(3):195-225

Easterly W (2003) Can foreign aid buy growth? J Econ Perspect 17:23-48

Ekanayake EM, Chatrna D (2010) The effect of foreign aid on economic growth in developing countries. J Int Bus Cult Stud 3:1-13

Feder G (1982) On exports and economic growth. J Dev Econ 12(1\&2):59-73

Greenaway D, Winters LA (eds) (1994) Surveys in international trade. Blackwell, Oxford (chs. 1-3, 6-8)

Harrison GW, Vinod HD (1992) The sensitivity analysis of applied general equilibrium models: completely randomized factorial sampling designs. Rev Econ Stat 74(2):357-362

Helble M, Wilson J, Mann C (2009) Aid for trade facilitation. World Bank Policy Research Working Paper, No. 5064

Hertel TW (1997) Global trade analysis modeling and applications. Cambridge University Press, Cambridge

Hoekman B, Wilson JS (2010) Aid for trade, building on progress today for tomorrow's future. World Bank Policy Research Working Paper, No.5361

Holder R (2004) Redistribution to rent seekers, foreign aid and economic growth. Working Paper, Universität Bern Volkswirtschaftliches Institut, Switzerland

Inanga EL, Mandah E (2008) Foreign aid finance and economic development: the case of two foreign aid financing agencies in Zambia. Int Res J Finance Econ 14:322-358

Krishna P, Guru S (2011) Trade and inequality in India. NBER Working Paper 17257

Levine R, Renelt D (1992) A sensitivity analysis of cross-country growth. Am Econ Rev 82(4):942-963

Meschi EF, Vivarelli M (2007) Globalization and income inequality, IZA Discussion Paper No. 2958

Morrissey O (2010) Aid and the financing of public social sector spending. In: Hujo K, McClanahan S (eds) Financing social policy: mobilizing resources for social development. Palgrave/UNRISD, Basingstoke

Morrissey O, Mbabazi J, Milner C (2002) Inequality, trade liberalization and growth. CSGR WP 102/02. Univeristy of Nottingham

Rajan RG, Subramanian A (2005) Aid and growth: what does the cross-country evidence really show? International Monetary Fund Workding Paper No. 05/127

Rosenstein-Rodan PN (1943) Problems of industralisation of Eastern and South-Eastern Europe. Econ J 53:202-211

Wacziarg R (2001) Measuring the dynamic gains from trade. World Bank Econ Rev 15(3):393-429

Werker E, Faisal AZ, Cohen C (2009) How is foreign aid spent? Evidence from a natural experiment. Am Econ J Macroecon 1(2):225-244

Winters LA, McCulloch N (2000). Approaches to linking trade and poverty, paper presented at Conference on Trade, Poverty and the Environment: methodologies for sustainability impact assessment of trade policy. University of Manchester. (www.man.ac.uk/idpm/iasdu/)

WTO (2006) Recommendations of the task force on aid for trade (27 July) WT/AFT/1

WTO/OECD (2011) Aid for trade at a glance 2011 showing results. doi:10.1787/9789264117471-en 